PAEDAGOGIA ChristianA

2/24 (2009) - ISSN 1505-6872

Jerzy Smolen ${ }^{*}$

Lublin

\title{
Formacja ludzka katechetów
}

Praca katechetyczna wymaga dziś, bardziej niż wczoraj, ogromnego wysiłku i ogromnej odwagi. Mimo iż od czasu do czasu za pomocą niektórych mediów masowych próbuje się deprecjonować zawód katechety, nagłaśniając, przeważnie nieuczciwie, pojedyncze smutne sytuacje z udziałem katechetów, zarówno duchownych, jak i świeckich, katecheci tworzą krag osób cieszących się autorytetem. Często zdarza się, że to katecheta proszony jest na negocjatora w trudnych szkolnych sprawach, że do katechety zwraca się z prośbą o pomoc w sytuacjach konfliktowych, że do katechety odwołują się dorośli i młodzi jako do specjalisty, autorytetu w ważnych kwestiach dotyczących życia. Również działalność katechetyczna nie ogranicza się tylko do zajęć szkolnych, katechetycznych, ale także poza szkołą katecheci włączają się czynnie w życie poszczególnych wspólnot parafialnych, angażując się w pracę różnych grup, stowarzyszeń, poradni, ośrodków, świetlic.

Formacja do posługi katechetycznej musi więc obejmować kilka istotnych wymiarów, które w sposób oczywisty przyczyniają się do pełnienia tych ważnych zadań. Obok formacji intelektualnej, duchowej, duszpasterskiej bardzo ważna jest formacja ludzka. Podkreślają to mocno odnośne dokumenty Kościoła, wskazując, że jest ona fundamentem tej wielopłaszczyznowej formacji katechetycznej.

\section{Dokumenty Kościoła o potrzebie formacji ludzkiej}

W Dyrektorium o postudze i życiu kapłanów czytamy, że:

formacja ludzka jest wyjątkowo ważna w dzisiejszym świecie, taką zresztą była zawsze. Prezbiter nie powinien zapominać, że jest człowiekiem wybranym spośród

${ }^{*}$ Ks. dr Jerzy Smoleń, psycholog, adiunkt w Katedrze Współczesnych Form Przekazu Wiary Katolickiego Uniwersytetu Lubelskiego Jana Pawła II. 
ludzi, by być w służbie ludziom. W celu uświęcenia się i osiagnięcia powodzenia w swojej misji powinien on wypracować taki zasób cnót ludzkich, które uczynią go godnym szacunku jego braci. Prezbiterzy powinni w sposób szczególny praktykować dobroć serca, cierpliwość, uprzejmość, siłę ducha, umiłowanie sprawiedliwości, zrównoważenie, wierność danemu słowu, stałość wobec dobrowolnie przyjętych zobowiązań itd. Jest ponadto ważne, by kapłan zastanawiał się nad swoją postawą społeczną, poprawnością różnych form relacji ludzkich, wartością przyjaźni, godnym sposobem bycia ${ }^{1}$.

Bardzo obszerny wykład na ten temat daje Jan Paweł II w Adhortacji apostolskiej Pastores dabo vobis. Omawiając wymiary formacji kapłańskiej, w której zawiera się formacja katechetyczna, formację ludzką nazwał jej niezbędnym fundamentem. Papież napisał między innymi:

formacja ludzka kapłana okazuje się szczególnie ważna ze względu na tych, do których skierowana jest jego misja. Właśnie po to, żeby jego posługa była po ludzku jak najbardziej wiarygodna i łatwa do przyjęcia, kapłan winien kształtować swą ludzką osobowość w taki sposób, by stawać się dla innych pomostem, a nie przeszkodą w ich spotkaniu z Jezusem Chrystusem, Odkupicielem człowieka. Konieczne jest, by kapłan, biorąc przykład z Jezusa, [...] umiał poznawać do głębi wnętrze człowieka, odgadywać trudności i problemy, ułatwiać spotkanie i dialog, zdobywać zaufanie i nawiązywać współpracę, wyrażać spokojne i zrównoważone sądy. Nie tylko więc dla osiagnięcia właściwej i koniecznej dojrzałości oraz realizacji samego siebie, lecz również ze względu na podejmowaną posługe przyszli kapłani powinni rozwijać w sobie zespół ludzkich cech, bez których nie można kształtować osobowości zrównoważonych, silnych i wolnych, zdolnych dźwigać ciężary duszpasterskiej odpowiedzialności. Potrzebne jest więc wychowanie do umiłowania prawdy, do prawości i rzetelności, do szacunku wobec każdej osoby, do poczucia sprawiedliwości, do wierności danemu słowu, do prawdziwego współczucia, do konsekwentnego postępowania, a zwłaszcza do zrównoważonego sądu i zachowania. [...] Szczególnie ważna jest zdolność do utrzymywania więzi z innymi, cecha naprawdę fundamentalna u kogoś, kto jest powołany, by ponosić odpowiedzialność za wspólnotę i być człowiekiem jedności. Dlatego kapłan nie może być arogancki ani kłótliwy, lecz uprzejmy, gościnny, szczery w słowach i w intencjach, roztropny i dyskretny, wielkoduszny i gotowy do służby, zdolny utrzymywać otwarte i braterskie kontakty z innymi i nawiązywać je ze wszystkimi, zawsze gotów zrozumieć, przebaczyć i pocieszyć².

Natomiast w Dyrektorium Ogólnym o Katechizacji zagadnienie formacji ludzkiej zostało ujęte w bardzo krótkiej triadzie: „być, wiedzieć, umieć dzia-

${ }^{1}$ Kongregacja ds. Duchowieństwa, Dyrektorium o postudze $i$ życiu kapłanów, Tarnów 1995, s. 90.

2 Jan Paweł II, Adhortacja apostolska Pastores dabo vobis, Rzym 1992, $\mathrm{nr} 43$. 
łać"3. Ta triada doskonale ujmuje całość zagadnienia formacji człowieka, nie tylko katechetycznej. To „być”, o którym mówi Dyrektorium, stanowi podstawę ludzkiej formacji.

\section{Formacja ludzka a dojrzałość osobowościowa}

Formacja ludzka tak powinna być organizowana i prowadzona, by wytyczała drogę do dojrzałej osobowości. Dla wielu czytelników z pewnością dziwnie to zabrzmi, ale tak jak nigdy nie jesteśmy w stanie osiagnąć pełnego poznania samych siebie, tak też nigdy nie będziemy w pełni dojrzali. Formowanie do dojrzałej osobowości to nic innego, jak tylko zdecydowanie aktywny proces zmierzający do tego, by człowiek przejął odpowiedzialność za własne życie i rozwijał się w mądry, jedyny, niepowtarzalny sposób. Osoba taka ma świadomość, że nie jest definitywnie spełniona, zamknięta, ale że ciągle musi się stawać, musi być otwarta, a także zdolna do uczenia się od innych i przekonana o tym, że powinna zdecydowanie wziąć własne życie w swoje ręce.

$\mathrm{Na}$ gruncie psychologii wypracowano kilka koncepcji dojrzałej osobowości $^{4}$, podając szereg kryteriów, które mają pomóc w ocenie, czy mamy do czynienia z dojrzałą osobowością, czy też nie. Wynikają one z różnych założeń teoretycznych. Nie wchodząc w szczegóły poszczególnych nurtów psychologicznych, można wyakcentować cechy wspólne, łączące owe koncepcje. Syntetyczne ujęcie, zaprezentowane poniżej, nie wyczerpuje zagadnienia, pełni jedynie funkcję pragmatyczno-ilustracyjna.

\subsection{Akceptacja siebie}

Leży ona u podstaw zarówno pasji własnego rozwoju, jak i wszystkich relacji interpersonalnych. Umiejętność wglądu w motywy własnego postępowania pozwala osobie na obiektywną jego ocenę. Osoba z poczuciem własnej wartości, o wysokiej samoocenie, potrafi stawiać czoła wyzwaniom, właściwie podchodzić do popełnianych błędów, wyciągając z nich konstruktywne wnioski. Potrafi również zdystansować się do nieuczciwych zarzutów i twórczo korzystać z uzasadnionej krytyki. Ma zaufanie do osobistych zdolności. Cechuje ją obiektywizm, samodzielność myślenia.

${ }^{3}$ Kongregacja ds. Duchowieństwa, Dyrektorium Ogólne o Katechizacji, Warszawa 1998, s. 201.

${ }^{4}$ Zob. Z. Chlewiński, Dojrzałość: osobowość, sumienie, religijność, Poznań 1991; K. Dyrek, Wspólnota zakonna środowiskiem ksztaltowania dojrzałej osobowości, „Życie konsekrowane” 3 (1995), s. 30-32; A. J. Nowak, Kryteria dojrzatej osobowości i dojrzatej wiary, „Colloquium Salutis" 8 (1976), s. 224-131; Z. Płużek, Psychologia pastoralna, Kraków 1991; W. Szewczyk (red.), Jak sobie z tym poradzić?, Tarnów 1994; D. Ziółkowski, Z zagadnień dojrzałości religijnej, „Znak” 23 (1971), s. 1587-1595. 


\subsection{Integracja osobowości}

Każdy człowiek jest istotą złożoną z tego, co psychiczne, fizyczne, duchowe. Proces integracji wewnętrznej prowadzi do harmonii w tej triadzie intrapersonalnej. Jej wyrazem staje się nabywanie odporności psychicznej, poczucie wewnętrznej harmonii. Taka osoba dąży do harmonii z otoczeniem, umie zrezygnować $\mathrm{z}$ osobistych ambicji stojących $\mathrm{w}$ sprzeczności z dobrem innych osób, nie odkłada rozwiązywania problemów, konfliktów, nie pozwala na gromadzenie się emocjonalnych napięć utrudniających funkcjonowanie.

\subsection{Hierarchia wartości}

Jest ona wypracowywana przez człowieka w ciagu całego jego życia poprzez przykład osób znaczących: rodziców, nauczycieli, katechetów, wychowawców, a także poprzez osobiste przemyślenia, doświadczenia, przeżycia. Zdefiniowanie hierarchii wartości ukierunkowuje człowieka na realizację jego życiowych celów, zarówno tych cząstkowych, jak i ostatecznych. Osoba o dojrzałej osobowości ma stałe wartości najwyższe. Cel życia staje się motywacją do działania w przeciwnościach. Z wartościami człowieka, poprzez cel życia, ściśle powiązany jest sens życia.

\subsection{Postawa wobec życia}

Wynika zarówno z integracji osobowości, jak i z dojrzałości emocjonalnej. Zakłada twórcze zagospodarowanie czasu, którym się dysponuje, odwagę i przedsiębiorczość. Istotnymi cechami tej postawy są radość życia, pasja działania, obejmująca dynamizm i optymizm działania.

\subsection{Rozumienie innych}

Postawa taka nastawiona jest na czynienie dobra. Charakteryzuje się dobrym współistnieniem z innymi, nawiązywaniem serdecznych relacji, poszanowaniem godności każdego człowieka, akceptacją niezależnie od jego przekonań, zachowań. Pozwala zawsze oddzielić zachowanie człowieka, jego czyny, od osoby.

\subsection{Dojrzałość uczuciowa}

Jej przejawem jest zdolność panowania nad własnymi emocjami, uczuciami i zachowanie właściwej równowagi pomiędzy wyrażaniem emocji i uczuć a ich 
kontrolą. To umiejętność radzenia sobie w sposób twórczy z różnego rodzaju problemami życiowymi bez potrzeby odreagowania emocjonalnego ${ }^{5}$, tak dzisiaj popularnego w interpretacjach ludzkich zachowań, zwłaszcza ludzi młodych.

\subsection{Gotowość do poświęceń}

Zawsze powinna ona uwzględniać przede wszystkim największe dobro drugiego człowieka, służąc jego rozwojowi.

\subsection{Twórczość i szerokość zainteresowań}

Dojrzewanie osobowe domaga się szerokich zainteresowań. One dają niezależność. Ponadto człowiek twórczy przejawia pasję życia, która jest wyrazem jego wewnętrznej kondycji.

\subsection{Realne poznanie świata}

Chodzi tutaj o zdolność odróżniania prawdy od pozorów, komentarzy i ocen innych. W tym celu niezbędne jest stawianie sobie pytań odnośnie do dokładności poznania i stopnia jego prawdziwości.

Podsumowując powyższe kryteria dojrzałej osobowości, można powiedzieć, że człowiek znajduje się w ciaggym procesie bycia i stawania się. Ten proces, trwający przez całe jego życie, ciagle powinien być udoskonalany, dostosowywany do warunków życia i możliwości człowieka. Od jakości tego osobowego rozwoju człowieka zależy jego rozwój społeczny, międzyludzki.

\section{Formacja ludzka a komunikacja interpersonalna}

Wywodzące się z języka łacińskiego communicatio ${ }^{6}$ oznacza „uczestnictwo, współudział, udzielenie komuś czegoś, wzajemne udzielanie wiadomości, naradzać się, omawiać, mieć z kimś coś wspólnego, jedność, użyczenie, doniesienie". Włączone przez języki nowożytne pojawiło się w wieku XIV, oznaczając „wejście we wspólnotę, uczestnictwo, komunię"7.

${ }^{5}$ Por. J. Dobson, Emocje - czy można im zaufać?, Warszawa 1992; D. Seamans, Uzdrawianie zranionych uczuć, Kraków 1992.

${ }^{6}$ A. Jougan, Stownik kościelny tacińsko-polski, Warszawa 1992, s. 127; K. Kumaniecki (oprac.), Stownik łacińsko-polski, Warszawa 1973, s. 101.

7 Tamże. 
Dobra komunikacja warunkuje nie tylko osobisty rozwój człowieka, ale również i efektywność jego działalności, w tym także katechetycznej. Dlatego w niektórych seminariach duchownych w Polsce przygotowywane są pilotażowe programy warsztatowe z komunikacji interpersonalnej, kapłani (katecheci) pracują bowiem przede wszystkim z ludźmi. Pracują w zespołach złożonych z ludzi różniących się między sobą pod względem wiekowym, temperamentalnym, charakterologicznym. Znaczna część, żeby nie powiedzieć większość, kapłanów pracujących $\mathrm{w}$ pojedynkę $\mathrm{w}$ parafiach nie radzi sobie $\mathrm{z}$ samotnością $\mathrm{i}$ nie umie nawiązać współpracy z innymi, w tym również z kapłanami.

Komunikacja interpersonalna jest zagadnieniem bardzo ważnym, dlatego na podstawie materiału z przeprowadzonych przeze mnie warsztatów z komunikacji interpersonalnej wśród katechetów, duchownych i świeckich spróbuję pokrótce omówić wybrane aspekty tego zagadnienia ${ }^{8}$.

\subsection{Czynniki utrudniające komunikację}

Czynników utrudniających komunikację bądźją całkowicie przekreślających jest naprawdę dużo. Obok wspomnianych już wyżej, takich jak różnica wieku, charakteru, temperamentu, można również wskazać następujące.

\subsubsection{Chroniczny brak czasu}

Większość ludzi, w tym również katechetów, jest tak bardzo zajęta, zapracowana, w ciagłym pośpiechu, że nie mają czasu, by po prostu być i towarzyszyć innym w ich rozwoju. Wspomniany już pośpiech sprawia, że nie umiemy siebie wzajemnie wysłuchać. Podczas edukacji szkolnej na różnych poziomach, czy nawet uniwersyteckiej, nikt na żadnych zajęciach nie uczył nas uważnego, cierpliwego słuchania drugiego człowieka. Stąd tyle trudności w nas, gdy trzeba zmierzyć się z tym problemem. Jakże często słyszy się w rozmowie: „wiem, wiem, o co ci chodzi" i przerywana jest rozmowa. A przecież, jak możemy poznać całość zagadnienia, problemu, z którym przychodzi do nas człowiek, nie wysłuchawszy

${ }^{8}$ Zob. J. Smoleń, Żeby być razem, „Gość Niedzielny” 1 (2004), s. 24; tenże, Jak dzisiaj spowiadać ludzi młodych?, w: J. Augustyn, S. Cyran (red.), Sztuka spowiadania. Poradnik dla księży, Kraków 2005, s. 241-249; tenże, Wybrane zagadnienia z komunikacji interpersonalnej $w$ życiu kapłańskim, w: P. Kurzela, A. Liskowacka (red.), Wychowanie młodych do wiary. Materiaty duszpasterskie, Katowice 2006, s. 42-54; tenże, O komunikacji interpersonalnej nie tylko na Święta, „Korona” 1 (2009), s. 5; tenże, Wartość komunikacji ,face to face” w dobie globalnej komunikacji. Zarys Zagadnienia, w: P. Kawałko, Z. Krzyszowski, S. Sieczka (red.), W stużbie piękna. Księga pamiatkowa poświęcona Księdzu Prałatowi Eugeniuszowi Kościótce z okazji 70-lecia urodzin, Lublin 2009, s. 143-147; tenże, Nie ,zamykaj” mnie, ale dodaj mi odwagi do Bycia, w: M. Kaczor, D. Świdkiewicz (red.), Wychowanie to dzieło Miłości, Zielona Góra 2009, s. 200-206. 
go do końca. Po prostu brakuje nam cierpliwości do zwyczajnego wysłuchania. Czasem trudność ta wywołana jest przez utożsamianie wysłuchania z posłuchaniem, a przecież pojęcia te nie są tożsame. Wysłuchanie kogoś nie obliguje mnie do posłuchania go, a więc do spełnienia jego życzeń, ale może stać się zaczynem twórczej dyskusji, twórczych rozwiązań. Ponadto wręcz powszechnym zjawiskiem staje się, że natychmiast - nie wysłuchawszy do końca - udzielamy rad, oceniamy, krytykujemy. Takie zachowanie dystansuje naszego rozmówcę. Tymczasem bardzo często wystarczy tylko to, że się po prostu jest, że się ma czas dla drugiego człowieka, że się autentycznie zainteresuje tym, z czym on przychodzi.

\subsection{2. „Zamykacze” zamiast „otwieraczy”}

Chodzi tutaj o słowa, które otwierają rozmówcę, pobudzają go, zachęcają do rozmowy, w których wyczuwa się zrozumienie, czyli „otwieracze” i o takie słowa, które go blokują, zamykaja, przy których wycofuje się, czując się niezrozumiałym, czyli, jak sama nazwa mówi, „zamykacze”. Łatwo przychodzi nam powiedzieć: „weź się w garść, poradzisz sobie, głowa do góry, spręż się, nie przejmuj się, będzie dobrze, daj spokój, a jeszcze częściej oddaj to Chrystusowi”. Takie stwierdzenia nie rozwiązują problemu, nawet nie otwierają na szczerą rozmowę, tylko zamykają, pozostawiają ze świadomością bycia niezrozumianym. Przychodzący wie, że ma się wziąć w garść. Bardzo chętnie oddałby to wszystko Chrystusowi, by nie cierpieć, ale gdyby wiedział, jak to zrobić, to najprawdopodobniej nie przyszedłby do nas, tylko poradziłby sobie sam. Skoro jednak przychodzi, to znaczy, że nie wie, jak sobie z tym poradzić.

\subsubsection{Znak równości między akceptacją a aprobatą}

Tymczasem pojęcia te również nie są tożsame. Stawiając znak równości, bardzo często grzech, ludzką słabość, ludzkie upadki utożsamiamy z człowiekiem. Przekreślając grzech, przekreślamy człowieka. Obdarzając akceptacją, przyjmuję człowieka takim, jaki jest, nie rezygnując przy tym ze swojego świata wartości, nie stawiając żadnych warunków na sam fakt spotkania. Aprobata zaś jest podpisaniem się całym sobą pod tym wszystkim, co czyni drugi człowiek, to jakby identyfikowanie się z nim. Myląc te pojęcia, krzywdzimy spotkane osoby. Każdy jest wrażliwy na akceptację ze strony drugich, a cóż dopiero młody człowiek, który uczy się siebie i życia.

\subsubsection{Brak empatii}

Nieumiejętność wczucia się w sytuację drugiego człowieka to naprawdę ogromne utrudnienie w komunikacji. Bardzo łatwo wówczas o niezrozumienie, 
zranienia czy wręcz krzywdy, które potem długo trzeba naprawiać, leczyć. Często zapomina się o tym, że to, co dla mnie nie stanowi trudności, problemu, dla innych może być, i zazwyczaj jest, naprawdę niemałym problemem. Nie popełnimy błędu komunikacyjnego w relacjach interpersonalnych, jeżeli autentycznie z troską i zrozumieniem podejdziemy do każdego zagadnienia, z którym przychodzi do nas człowiek, jeśli nie pozwolimy sobie na, choćby odrobinę, lekceważenia, ośmieszenia, zignorowania owego problemu.

\subsubsection{Zmęczenie}

Mało jest zrozumienia dla dnia wolnego w tygodniu. Iluż starszych księży nie umie tego jeszcze zaakceptować. A przecież nie można pięknie, twórczo pracować, będąc zmęczonym. Zmęczenie często jest przyczyną naszego rozdrażnienia, niecierpliwości. Wówczas pada wiele niepotrzebnych słów, komentarzy, które potem trudno naprawić.

Odpoczynek jest wpisany w nasze istnienie, w działalność człowieka. Sam Jezus Chrystus nauczał Apostołów: „Pójdźcie wy sami osobno na miejsce pustynne i wypocznijcie nieco" (Mk 6, 31). Odpoczynek jest potrzebny po każdej pracy, a zwłaszcza po pracy z ludźmi. Kontakt z człowiekiem, tak jak daje ogrom satysfakcji, tak też pozostawia zmęczenie. Dobrze zregenerowane siły psychiczne, fizyczne i duchowe stają się podstawą do twórczej działalności. Oczywiście kwestia dobrego odpoczynku to kolejne zagadnienie, które wymaga osobnej refleksji, osobnego opracowania.

\subsubsection{Uprzedzenia i stereotypy}

Wręcz szokujący, i nie do przyjęcia, jest styl bycia pisany uprzedzeniami do człowieka lub grupy osób, przez pryzmat obiegowych opinii, komentarzy, ocen czy też stereotypów. Katecheta nigdy nie może sobie na to pozwolić pod żadnym pozorem, nawet gdyby kiedykolwiek ucierpiał on sam, bądź ktoś z jego bliskich, przez daną osobę czy grupę osób. Tym samym daje on świadectwo swojej dojrzałości bądź niedojrzałości osobowościowej. Wiele konfliktów powstających na linii katecheta-uczeń, ma swoje źródło właśnie w uprzedzeniach, które skutecznie potrafią zamykać na poprawną komunikację międzyludzką.

\subsubsection{Brak jasnych zasad}

Ważne, by zasady współpracy, zdobywania ocen były czytelne, jasne i takie same dla wszystkich. Zmienianie ich w trakcie wykonywania zadania albo w zależności od humoru, sympatii jest niedopuszczalne. Rodzi tylko konflikty, stany 
lękowe, nerwicowe, podważa zaufanie i szacunek, nie daje żadnej satysfakcji $\mathrm{z}$ wykonywanej pracy, lecz często prowadzi do rezygnacji z działania.

\subsubsection{Zazdrość}

To jeden z grzechów głównych, który odbiera trzeźwość myślenia. Utrudnia wprowadzanie czegoś nowego w duszpasterstwie, katechizacji. W wielu przypadkach blokuje aktywność innych, ich inwencję twórczą albo wywołuje rywalizację zamiast współpracy. „Bo nie” - to główny argument, który się wówczas najczęściej słyszy.

\subsubsection{Wielkie kwantyfikatory}

Chodzi o wypowiedzi typu „nigdy (bym tego nie zaakceptował)”, „zawsze (nic ci się nie udaje)”, „wszyscy (potrafią coś zrobić, tylko nie ty)” albo „nie wyobrażam sobie (żeby mieć taki problem)". W kontekście całych wypowiedzi te zwroty potrafią być „zamykaczami”. Osoby potrzebujące pomocy, przeżywające kryzys, słysząc takie stwierdzenia nie odważą się przyjść ze swoim problemem do nas, bo będą bały się niezrozumienia, odrzucenia czy wręcz potępienia. Kiedy rozmawiam z byłymi księżmi, na pytanie, czy nie było już innego rozwiązania, słyszę: „nie miałem z kim o tym porozmawiać”. „Dlaczego?” „Bo wszyscy sprawiali wrażenie idealnych, a ich sądy były tak kategoryczne, że odbierało mowę."

\subsubsection{Niedopowiedzenia}

Ileż to razy na pytanie: „czy zapytałeś o to, czy powiedziałeś o tym?”, można usłyszeć „,powinien domyślić się”. Czyż nie byłoby uczciwiej i prościej po prostu powiedzieć, a nie czekać, czy się domyśli? Prowadząc zajęcia z uważnego słuchania, zawsze pytam poszczególnych uczestników, czy chcą o coś dopytać, czy wszystko jest dla nich jasne, może coś powtórzyć? Sporadycznie zdarza się, że ktoś skorzysta z tej sugestii i o coś dopyta. Zazwyczaj uważają że tego nie potrzebują. Dopiero w dalszej części ćwiczenia doświadczają swojego błędnego podejścia, zbytniego zaufania sobie i pewności siebie.

\subsubsection{Ciche dni}

Zerwać komunikację i nie rozmawiać z kimś przez jakiś okres. Nie rozmawiać $\mathrm{z}$ dorosłymi, nie rozmawiać z dziećmi, uczniami. Jest to najbardziej pry- 
mitywna forma ludzkiego zachowania. Człowiek, który zrywa komunikację, zabiera sny, zabierając sny - zabija, a to nie jest godne żadnego człowieka, a cóż dopiero człowieka odpowiadającego za formację innych, o którym mówią alter Christus. I nie wolno już thumaczyć się trudnym dzieciństwem, wyjątkowymi doświadczeniami z przeszłości. To trzeba zmienić.

\subsubsection{Forma przekazu}

I w tej materii jest wiele do życzenia. Irytuje nas, gdy jesteśmy traktowani z góry, lekceważąco, ale sami mamy tendencje do takiego traktowania innych, zarówno dorosłych, jak i swoich uczniów. Dużo łatwiej przyjmuje się uwagę przekazaną z życzliwością, kulturą, troską i ze zrozumieniem dla ludzkiej niedoskonałości, i co ważne, dyskretnie w cztery oczy.

\subsubsection{Język przekazu}

Prawdopodobieństwo nawiązania dobrej komunikacji, bycia zrozumianym jest tym większe, im bardziej proste, ale nie banalne, jest nasze słownictwo. Używanie wyszukanej terminologii, niedostosowanej do poziomu rozmówcy gwarantuje jedynie niezrozumienie czy nawet odrzucenie.

\subsubsection{Presja autorytetu}

Zawód nauczyciela, katechety, jak już powiedziałem we wstępie, w wielu środowiskach cieszy się ogromnym zaufaniem. Zdanie katechety jest bardzo ważne. Często są oni zapytywani na różne tematy, nie tylko przez uczniów, ale również przez swoich kolegów nauczycieli czy też rodziców. Stąd u wielu z nich rodzi się przekonanie, że powinni oni zawsze znać odpowiedź na każde pytanie. Jeżeli tej odpowiedzi nie znają, to czują się co najmniej niezręcznie, żeby nie powiedzieć, że koszmarnie zmęczeni taką sytuacją. Takie zachowanie wywołuje u nich reakcję lęku przed wykazaniem jakby ich „niekompetencji”. Wówczas mechanizmem obronnym staje się często wysłanie „zamykacza”, ucinającego dalszą rozmowę, pozornie tylko zakrywającego brak odpowiedzi. Tymczasem czymś jak najbardziej naturalnym i przede wszystkim uczciwym jest przyznanie się do tego, że nie zna się odpowiedzi na jakieś pytanie, niż udzielanie odpowiedzi nie wiedząc samemu, o czym się mówi, czy też „zamykając” słuchaczy. Dużo jest w tym zachowaniu egoistycznego koncentrowania się tylko na sobie (,,ja muszę znać odpowiedź”, ,ja muszę się dobrze zaprezentować”, ,ja nie mogę pokazać swojej luki w wykształceniu”, „to mnie nie wypada”). Takie koncentrowanie się tylko na sobie niczego dobrego nie wnosi w relacje interpersonalne. 


\subsection{Kilka propozycji na udaną komunikację}

Aby komunikacja dawała satysfakcję, trzeba się o nią zatroszczyć. Trzeba się ciagle uczyć zarówno siebie, jak i drugiego człowieka. Harmonia intrapersonalna, a więc w tym, co jest we mnie w obszarze psychicznym, fizycznym, duchowym, warunkuje harmonię interpersonalną. Jeżeli we mnie jest rozdrażnienie, komunikuję rozdrażnieniem, jeżeli jest pokój, komunikuję pokojem, jeżeli jest cały świat kompleksów, komunikuję poprzez pryzmat własnych kompleksów, jeżeli jest odwaga do życia, przekazuję ją innym.

Oto kilka propozycji dla tych, którzy pragną prywatnie, z troską pochylić się nad sztuką komunikowania sięe:

1. Nie ,zamykaj” innych. Wykreśl ,zamykacze” ze swojego prywatnego i zawodowego słownika;

2. Po prostu bądź blisko. Miej czas by być, towarzyszyć, wysłuchać.

3. Nie śpiesz się z udzielaniem rad, z pouczaniem. Nie każdy tego oczekuje;

4. Miej szacunek dla każdego, z czymkolwiek przychodzi. Każdy człowiek jest darem dla nas;

5. Bądź otwarty na drugich. Zaakceptuj, że są inni. Nikt nie jest taki sam jak Ty;

6. Dbaj, by każdy odchodził od Ciebie z nadzieją;

7. Bądź godny zaufania. Największe tajemnice powierzone ci w zaufaniu pamiętaj tylko dla siebie;

8. Nie używaj wielkich kwantyfikatorów: nigdy, zawsze, wszyscy, nie wyobrażam sobie. Nikt z nas nie jest przecież aniołem;

9. Dostrzegaj nie tylko błędy, ale przede wszystkim dobre strony drugiego;

10. Nie wstydź się powiedzieć coś miłego, ciepłego. Przecież sam tego potrzebujesz;

11. Każdemu daj szansę, ale nie bądź naiwny;

12. Pamiętaj o gestach, nawet bez słów;

13. Odpoczywaj, by nie irytowały, nie rozdrażniały cię byle głupstwa.

\section{Zakończenie}

Bycie katecheta, wychowawca, nauczycielem nie jest proste. Trzeba ciagle uczyć się:

radzić sobie w tym zawodzie $\mathrm{z}$ wieloma zjawiskami i ograniczeniami wynikającymi z naszej natury, kultury czy wychowania. Każdy, kto uprawia ten zawód, musi się

9 Por. J. Smoleń, Nie „zamykaj” mnie..., s. 205-206. 
liczyć z koniecznością ciągłego podnoszenia kompetencji. Bardzo wielu dydaktyków i pedagogów ma problemy z przekazywaniem swojej wiedzy i umiejętności, ponieważ zbagatelizowali oni zagadnienia z zakresu komunikacji ${ }^{10}$.

Formacja ludzka, tak mocno dzisiaj akcentowana, nie jest prosta. Wymaga zaangażowania ze wszystkich stron. Wymaga wysiłku, który zawsze przynieść może tylko radość, a nigdy znużenie. To bardzo syntetyczne i wycinkowe spojrzenie nie wyczerpuje całości zagadnienia, jest tylko jego zarysowaniem, a przede wszystkim jest zaproszeniem do twórczego pochylenia się z troską nad sobą i drugim człowiekiem, przygotowując dla niego takie warunki edukacyjne i komunikacyjne, by nigdy nie zamykały go na rozwój, na życie. Potrzeba dzisiaj katechetów obdarzonych ,głęboką wiarą, wyrazistą tożsamością chrześcijańską i eklezjalną oraz głęboką wrażliwością społeczną"l1, czyli ludzką.

\section{Human formation of catechists (Summary)}

Formation to catechetical service entails several important dimensions which in an evident way contribute to the fulfillment of substantial didactic and educational tasks.

Apart from intellectual, spirituals and pastoral formation, it is human formation which is also vital. It should be organized and carried out in such a way so that it would define the path leading to a mature personality that conditions proper interpersonal relations. This fact is strongly emphasized in relevant Church documents which indicate that human formation constitutes the basis for the multi-level catechetical formation. However, this human formation, so emphasized nowadays, is not simple. On the contrary: it requires the engagement from all sides as well as efforts that could always lead only to happiness, not to weariness.

${ }^{10}$ K. Bocheńska, Szach-mat, czyli o komunikacji w rzeczywistości szkolnej, Warszawa 2006, s. 9.

${ }^{11}$ Kongregacja ds. Duchowieństwa, Dyrektorium Ogólne, s. 200. 